\section{Миронова И.А.*, Образцов П.И.}

\author{
Технология обучения как способ формирования индивидуального \\ творческого стиля деятельности у студентов архитекторов \\ и градостроителей в вузе
}

\author{
Орловский государственный университет имени И.С. Тургенева \\ ул. Комсомольская, д. 95, г. Орел, 302026, Россия \\ hatshepsoote@yandex.ru*
}

Статья поступила 29 января 2020; принята 09 марта 2020; опубликована 31 марта 2020

Аннотация. Востребованность обновления содержания высшего архитектурноградостроительного образования обусловлена сменой образовательной парадигмы на личностно-развивающую. Базируясь на результатах анализа профессиональных и образовательных стандартов, предмета деятельности, целей и задач Российской академии архитектуры и строительных наук, а также результатах опроса - интервьюирования представителей профессионального архитектурно-градостроительного сообщества, авторы статьи делают вывод о необходимости формирования индивидуального творческого стиля деятельности у студентов архитекторов и градостроителей в процессе получения высшего профессионального образования. Целью исследования стала разработка соответствующей технологии. В результате приведены итоги констатирующего эксперимента, показывающие необходимость менять подходы к передаче материала, касающегося творческих дисциплин: следует наполнять содержание образования методиками, способствующими формированию стабильного интереса к творческой деятельности, стремления к самостоятельному поиску профессионально значимых знаний и умений, стремления к осуществлению творческой деятельности по собственной программе. В качестве средства реализации педагогических целей эффективной подготовки квалифицированных кадров с сформированными индивидуально-творческими профессионально значимыми качествами предлагается рассматривать профессионально ориентированную технологию образовательного процесса, способствующую формированию индивидуального творческого стиля деятельности у студентов архитекторов и градостроителей. Рассмотрены основные этапы и последовательность действий, которые отображают образовательный процесс. Выделены генеральные и проприетарные цели. Показано, что цели, поставленные при конструировании технологии образовательного процесса, полностью коррелируют с профессиональными компетенциями, установленными образовательной программой для рассматриваемых дисциплин. Рассмотрены особенности подбора содержания, а также выбора методов и форм организации познавательно-творческой деятельности обучающихся. Указана предпочтительность следующих методов: метод кейсов, метод моделирования, использование различных методик развития творческого потенциала и настройки на творческую деятельность. Представлен разработанный критериально-оценочный блок, отражающий основные критерии и показатели, а также уровни сформированности индивидуального творческого стиля деятельности у студентов. Включенное наблюдение, метод беседы, интервью, метод рейтинга и метод педагогического консилиума определены как основные эмпирические методы диагностического контроля. Делается вывод о том, что предлагаемая технология обучения будет способствовать успешному формированию 
индивидуального творческого стиля деятельности студентов архитекторов и градостроителей в вузе.

Ключевые слова: индивидуальный творческий стиль деятельности; архитектурно-градостроительное образование; профессионально ориентированная технология образовательного процесса; педагогика творчества; теоретическая модель; содержание образования.

Информация для цитирования: Миронова И.А., Образцов П.И. Технология обучения как способ формирования индивидуального творческого стиля деятельности у студентов архитекторов и градостроителей в вузе // Научный результат. Педагогика и психология образования. 2020. Т.6. №1. С. 26-40. DOI: $10.18413 / 2313-8971-2020-6-1-0-3$

\title{
I.A. Mironova*, Education technology as a way to form an individual creative style P.I. Obraztsov of activity for students of architecture and urban planning at university
}

Orel State University named after I.S. Turgenev, 95, Komsomolskaya Str., Orel, 302026, Russia hatshepsoote@yandex.ru*

Received on January 29, 2020; accepted on March 09, 2020; published on March 31, 2020

\begin{abstract}
The demand for updating the content of higher architectural and urban planning education is explained by the change of the educational paradigm to a personalitydeveloping paradigm. Based on the results of the analysis of professional and educational standards, activities, goals and objectives of the Russian Academy of Architecture and Construction Sciences, as well as the results of a survey - interviewing representatives of the professional architectural and urban planning community - the authors of the article conclude that it is necessary to form an individual creative style of activity for students of architecture and urban planning in the process of obtaining higher professional education. The article also presents the results of an experiment showing the need to change approaches to the transfer of academic material relating to the artistic disciplines, to fill the contents of education with methods contributing to the formation of steady interest to creative activity, aspiration to independent research of professionally significant knowledge and skills, striving for the realization of creative activities on their own program. As a means of implementing the pedagogical goals of effective training of qualified personnel with formed individual creative professionally significant qualities, it is proposed to consider a professionally oriented technology of the educational process that contributes to the formation of an individual creative style of activity among students of architecture and urban planning. The main stages and sequence of actions that reflect the educational process are considered in this work. General and proprietary goals are highlighted. It is shown that the goals set when designing the technology of the educational process are fully correlated with the professional competencies established by the educational program for the disciplines under consideration. The features of the selection of content, as well as the choice of methods and forms of organization of cognitive and creative activity of students are considered. The following methods are preferred: the case study method, the modeling method, the use of various
\end{abstract}


methods for developing creative potential and setting up creative activities. The developed block of criteria and evaluation is presented, which reflects the main criteria and indicators, as well as the levels of formation of individual creative style of activity among students. The included observation, conversation method, interview, rating method, and pedagogical consultation method are defined as the main empirical methods of diagnostic control. It is concluded that the proposed training technology will contribute to the successful formation of an individual creative style of activity of students of architects and urban planners at the University.

Keywords: individual creative style of activity; architectural and urban planning education; professionally oriented technology of the educational process; pedagogy of creativity; theoretical model; content of education

Information for citation: Mironova I.A., Obraztsov P.I. (2020), "Education technology as a way to form an individual creative style of activity for students of architecture and urban planning at university", Research Result. Pedagogy and Psychology of Education, 6 (1), 26-40, DOI: 10.18413/2313-8971-2020-6-1-0-3

Введение (Introduction). Обновление системы высшего архитектурного и градостроительного образования, обусловленное сменой образовательной парадигмы на личностно-развивающую, влечет за собой, в первую очередь, изменение его содержания. Основной вектор развития современных систем образования и, в том числе, высшего архитектурно-градостроительного образования направлен в сторону стратегии обучения в течение всей жизни, а воспитание творческой личности, способной к дальнейшему постоянному саморазвитию становится одной из главных задач образовательной системы.

Результаты анализа профессиональных стандартов архитектора и градостроителя, Федеральных государственных образовательных стандартов и образовательных программ по направлениям «Архитектура» и «Градостроительство», а также предмета деятельности, целей и задач Российской академии архитектуры и строительных наук (РААСН) позволяют сделать вывод о том, что творчество является неотъемлемой частью профессиональной деятельности архитектора и градостроителя, а необходимость саморазвития и самообразования в течение всей жизни признается государством и профессиональным сообществом. Следовательно, можно говорить о необходимости формирования в образовательном процессе у студентов архитекторов и градостроителей индивидуального творческого стиля деятельности, позволяющего не только максимально раскрыть профессиональный творческий потенциал, но и реализовать концепцию постоянного самообразования и саморазвития творческой личности в течение всей жизни.

С целью получения наиболее полной картины о необходимости наличия индивидуального творческого стиля деятельности у практикующих архитекторов и градостроителей было принято решение о проведении опроса - интервьюирования среди профессионалов, осуществляющих архитектурную и градостроительную деятельность. В частности, опрос - интервьюирование проводился среди руководства и сотрудников Управления градостроительства, архитектуры и землеустройства Орловской области, Управления градостроительства администрации города Орла, были проинтервьюированы председатель и члены орловского регионального отделения общероссийской творческой профессиональной общественной организации «Союз архитекторов России», руководители творческих студий и мастерских, осуществляющих коммерческую деятельность в области архитектуры и градостроительства (генеральный директор ООО «Аспект»), а также архитекторы, осуществляющие практическую деятельность в 
сфере архитектуры и градостроительства и не относящиеся к руководящему звену (главный архитектор проектов ОАО «Гражданпроект» Орел, архитекторы ООО «Аспект» Орел, ООО «Дизайн бюро» Орел, ОАО «Гражданпроект» Орел, архитектор ООО «Архитектурная мастерская Цехомского В.В.» Санкт-Петербург).

Интервью содержало два основных вопроса:

1. Является ли необходимым наличие индивидуального творческого стиля деятельности у архитекторов и градостроителей при осуществлении ими практической деятельности?

2. Важно ли формировать индивидуальный творческий стиль деятельности у студентов архитекторов и градостроителей в процессе получения профессионального образования?

Bce опрошенные дали однозначный утвердительный ответ на поставленные вопросы, отмечая важность стилевой творческой составляющей профессии, а также указали на сложности, с которыми приходится сталкиваться при профессиональной работе с молодыми специалистами выпускниками вуза, у которых эта компонента не сформировалась в процессе обучения. В частности, указывалось на инфантильность в ситуациях, требующих принятия творческого решения, неспособность и нежелание осуществлять систематический анализ профессиональной проблематики и творческий поиск различных путей разрешения проблем, стереотипное мышление, отсутствие стремления к самообразованию и саморазвитию, несформированность личностных смыслов содержания профессиональной творческой деятельности и т.п.

Обобщая вышеизложенную информацию можно с уверенностью говорить о назревшей потребности формирования индивидуального творческого стиля деятельности у студентов архитекторов и градостроителей в вузе.

Исходя из данного утверждения, целью исследования явилась разработка и описание технологии обучения, способ- ствующей формированию индивидуального творческого стиля деятельности у студентов архитекторов и градостроителей в вузе.

Основная часть (Main Part). Для того, чтобы формирование индивидуального творческого стиля деятельности у студентов архитекторов и градостроителей в вузе проходило успешно, необходима целенаправленная организация образовательного процесса, результатом которого будет являться эффективная подготовка квалифицированных кадров с сформированными индивидуально-творческими профессионально значимыми качествами. Следовательно, требуется профессионально ориентированная технология образовательного процесса, способствующая формированию индивидуального творческого стиля деятельности у студентов архитекторов и градостроителей.

«Технология образовательная (от греч. techne - искусство, мастерство, умение и $\operatorname{logos}$ - понятие, мысль, разум) - 1) системный метод воспроизведения педагогического процесса на основе апробированных и логически выстроенных процедур обучения и воспитания, оптимизирующих образовательный процесс, с определенной степенью вероятности обеспечивающий получение планируемых результатов» (Загвязинский, 2008:29).

Из российских педагогов наибольший вклад в разработку проблемы технологии обучения внесли В.П. Беспалько, В.С. Зайцев, Н.В. Кузьмина, П.И. Образцов, Г К. Селевко, В.В. Сериков, В.А. Сластенин, С.А. Смирнов, А.И. Уман и другие. Из зарубежных исследователей следует отметить Л. Андерсона, Дж. Блока, Б. Блума, Т. Гилберта, Р. Мейджера и других.

В основе технологии образовательного процесса, ориентированного на формирование индивидуального творческого стиля деятельности у студентов архитекторов и градостроителей лежит проектирование целостного дидактического процесса, базирующееся на обобщенном накопленном опыте формирования профессионально-значимых компетенций, развития индивидуальнотворческих характеристик обучающихся, 
воздействия на механизмы личностного и профессионального развития. При этом В.С. Зайцев рассматривает педагогическое проектирование, как:

1) разработку педагогического проекта;

2) процедуру, которая состоит в информационной подготовке некоторых изменений педагогической реальности, в предварительном осмыслении и описании таких изменений в форме конкретных действий участников педагогического процесса (В.С. Зайцев, 2014).

С учетом анализа методологии педагогического проектирования, а также теоретических исследований и практического опыта в архитектурной педагогике и педагогике творчества, предлагается также следующая последовательность:

1) определение целей;

2) подбор содержания образования с учетом процессуальных механизмов педагогической поддержки личностно-творческого развития и формирования индивидуального творческого стиля деятельности;

3) выбор методов и форм организации познавательно-творческой деятельности обучающихся;

4) определение форм и средств контроля.

Исследователи педагогических теорий, систем и технологий подчеркивают, что ведущую роль в педагогических технологиях играет средство обучения. При этом, по мнению ученых, педагог выполняет функции стимулирования и координации деятельности обучающихся (С.А. Смирнов, И.Б. Котова, Е.Н. Шиянов и др.).

Рассматривая вопрос образовательных технологий с позиций личностноразвивающей образовательной парадигмы, следует признать обязательным наличие личностного и творческого аспекта в проектируемых современных образовательных процессах, а также уверенно говорить о ведущей роли личностно-творческого аспекта образовательной технологии для архитектурного и градостроительного образования.

В.В. Сериков видит личностноориентированное образование в создании условий, при которых каждый отдельно взятый индивид может проявлять и развивать свои личностные функции. А то, насколько полно эти функции представлены в деятельности в учебном процессе, В.В. Сериков считает показателем личностно-развивающего уровня (В.В. Сериков, 2012).

Необходимо отметить, что такую личностную характеристику как стиль, в том числе, такую профессионально значимую, как индивидуальный творческий стиль деятельности архитектора и градостроителя не представляется возможным сформировать в рамках какой-либо единичной дисциплины. Следовательно, при технологическом конструировании надлежит задействовать целый ряд значимых для формирования профессиональных характеристик архитектора и градостроителя дисциплин. В частности, основой для проектирования и конструирования технологии формирования индивидуального творческого стиля деятельности архитектора и градостроителя в вузе послужили такие дисциплины как архитектурное проектирование (I уровень), архитектурноградостроительное проектирование (I уровень), архитектурная колористика, градостроительная колористика, подземная урбанистика, основы подземной урбанистики в градостроительном проектировании, дизайн интерьера, творческий стиль в профессиональной деятельности градостроителя, методология архитектурного проектирования устойчивой среды обитания, профессиональная практика (архитектурное законодательство и нормирование, архитектурная этика, архитектурный менеджмент и администрирование). Так как каждая дисциплина имеет свои четко обозначенные цели и задачи, которые будут достигаться и решаться в рамках ее освоения, цели разработанной нами образовательной технологии формирования индивидуального творческого стиля деятельности у студентов архитекторов и градостроителей носят признаки системы с выстроенной иерархией. И, как следствие, имеют несколько уровней, показывающих их приоритет: 
1) общий (генеральный) уровень целеполагания, отражающий суть педагогического замысла в целом и результат, получаемый при применении данной технологии обучения в образовательном процессе;

2) частный, отражающий конкретный желаемый результат в среднесрочной (цель изучаемой дисциплины, выполняемой курсовой или расчетно - графической работы) и краткосрочной перспективе (цель занятия, цель практического задания и т.п.)

При этом генеральные цели в такой конструкции влятюся своего рода осевым стержнем, который пронизывает архитектурно - градостроительный образовательный процесс и обобщает достигнутые в рамках каждой конкретной дисциплины результаты, переводя их на новый личностно творческий уровень профессионального развития обучающихся.

Цели, поставленные на частном уровне (в рамках занятия или при выполнении курсовых или расчетно-графических работ), необходимо максимально конкретизировать. Для этого необходим анализ особенностей педагогики творчества и изучение открывающихся возможностей, в контексте реализации поставленных целей. Далее определяются конкретные задачи, которые необходимо решить в рамках учебного процесса. Задачи могут быть как коллективными (кейсовые задания, хакатоны, мастерклассы и т.п.), так и индивидуальнотворческими (клаузуры, творческие задания на практических занятиях, курсовые и расчетно-графические работы и т.п.). При этом, краткосрочные и среднесрочные цели, будучи достигнутыми, являются слагаемыми успеха в формировании индивидуального творческого стиля деятельности у будущих архитекторов и градостроителей.

Например, для практического занятия, связанного с выполнением клаузуры по дисциплине «Основы подземной урбанистики в градостроительном проектировании», формулируются следующие цели:

- генеральные (общего порядка):

1) развитие профессионально значимых личностных творческих качеств студентов;
2) создание условий для формирования индивидуального творческого стиля деятельности.

- частного (проприетарного) порядка:

1) обеспечить выполнение студентами творческого задания, направленного на устранение психологических барьеров творческой свободы самовыражения;

2) направить вектор учебнотворческой деятельности студентов на выявление и осознание собственных творческих возможностей в процессе выполнения творческого задания;

3) создать условия для развития у студентов положительной мотивации к рефлексивному осмыслению профессионального творчества не только в процессе выполнения творческого задания, как такового, но и в процессе подготовки к заданию и после его выполнения;

4) создать условия для развития у студентов интереса к профессиональному творчеству и стремления к осознанной профессиональной творческой деятельности;

5) повысить качество владения графическими методами и средствами подачи проектного материала, а также расширить их диапазон, путем знакомства с новыми методами и средствами архитектурной графики.

Необходимо отметить, что когда речь идет о положительной мотивации к осмыслению творчества, интересе и стремлению к осознанной творческой деятельности, следует иметь в виду, что студенты, избравшие себе в качестве будущей профессии архитектуру или градостроительство, как правило, имеют представление о творческой составляющей этих профессий. Таким образом, можно говорить об изначальном присутствии у большинства обучающихся такой профессионально значимой характеристики, как положительная мотивация к творчеству. В то же время, степень сформированности этой характеристики у студентов может достаточно сильно разниться и, безусловно, требует предварительной диагностики и дальнейшей целенаправленной 
педагогической деятельности по ее дальнейшему формированию.

Необходимо также отметить, что, решая вопросы целеполагания на частном уровне, в рамках конкретной дисциплины, необходимо опираться на требования образовательных стандартов. Так, например, цели, поставленные в рамках дисциплины «Основы подземной урбанистики в градостроительном проектировании» при конструировании технологии образовательного процесса, полностью коррелируют с профессиональной компетенцией ПК-6, установленной образовательной программой для рассматриваемой дисциплины в соответствии с федеральным государственным образовательным стандартом: способность грамотно представлять градостроительный замысел, передавать идеи и проектные предложения, изучать, разрабатывать, формализовать и транслировать их в ходе совместной деятельности средствами устной и письменной речи, макетирования, ручной и компьютерной графики, количественных оценок ${ }^{1}$. При этом, в соответствии с образовательной программой высшего образования для направления «Градостроительство» уровень бакалавриат «Орловского государственного университета имени И.С. Тургенева» устанавливаются следующие индикаторы сформированности данной компетенции (табл. 1).

Одним из требующих особого внимания аспектов при проектировании технологии образовательного процесса для будущих архитекторов и градостроителей, является необходимость создания таких условий, при которых творчество пронизывает всю структуру образовательного процесса, проявляясь не только в графике, но и в других различных формах квазипрофессиональной деятельности студентов архитекторов и градостроителей. Например, если при поста-

\footnotetext{
1 Федеральный государственный образовательный стандарт высшего образования по направлению подготовки 07.03.04 Градостроительство уровень бакалавриат. Утвержден Мин. Образования и науки 02.03.2016 Г. № 41306 URL: http://fgosvo.ru/uploadfiles/fgosvob/070304_B_1506201 8.pdf (дата обращения: 15.10.2019)
}

новке частных целей для практического занятия по дисциплине «Основы подземной урбанистики в градостроительном проектировании» (уровень бакалавриат) акцент делается на умение передать творческий замысел проектировщика при помощи графических средств и методов, то при постановке проприетарных целей для практических занятий по дисциплине «Профессиональная практика (архитектурное законодательство и нормирование, архитектурная этика, архитектурный менеджмент и администрирование)» (уровень магистратуры) акцент смещается в сторону осуществления действий по поиску, получению и обработке информации (анализ, структурирование, обобщение и т.п.), архитектурно-градостроительному прогнозированию и принятию управленческих решений. Цели, касающиеся графической составляющей при выполнении данного задания, перестают играть главенствующую роль, при этом оставаясь актуальными.

Несмотря на то, что в приведённых примерах для целеполагания выбраны дисциплины разных уровней образовательной программы (бакалавриата и магистратуры), важно понимать, что формирование индивидуального творческого стиля деятельности у будущих архитекторов и градостроителей не ограничивается рамками какоголибо образовательного уровня, или дисциплины. Это непрерывный процесс индивидуального творческого самосовершенствования, основы которого закладываются на начальных этапах профессионального образования, и который затем постепенно развивается и совершенствуется не только в рамках получения высшего профессионального образования, но и в течение всей профессиональной жизни.

Следовательно, определяя и формулируя цели для дисциплин различного образовательного уровня, при проектировании и конструировании образовательной технологии, необходимо, исходя из определенных образовательными стандартами компетенций, направить процесс их формирования в индивидуально-творческое русло. 
Индикаторы достижения сформированности профессиональной компетенции ПК-6

\section{Indicators of achievement of professional competence formation PC-6}

\begin{tabular}{|c|c|}
\hline $\begin{array}{c}\text { Код } \\
\text { компетенции }\end{array}$ & $\begin{array}{c}\text { Индикаторы достижения компетенции (для планирования } \\
\text { результатов обучения по образовательной программе) }\end{array}$ \\
\hline \multirow{3}{*}{ ПК-6 } & $\begin{array}{l}\text { Знать: методы наглядного изображения и моделирования плоскостной и } \\
\text { трехмерной формы и пространства, актуальные средства развития и вы- } \\
\text { ражения градостроительного замысла (графические, макетные, компью- } \\
\text { терные, вербальные, видео и др.); особенности восприятия визуальной } \\
\text { информации в различных её формах и представлениях }\end{array}$ \\
\hline & $\begin{array}{l}\text { Уметь: выполнять архитектурные и градостроительные эскизы, чертежи; } \\
\text { выбирать формы, методы, стили и средства изображения и моделирова- } \\
\text { ния архитектурно-градостроительной формы и пространства; транслиро- } \\
\text { вать проектные предложения средствами устной и письменной речи; ко- } \\
\text { личественных оценок }\end{array}$ \\
\hline & $\begin{array}{l}\text { Владеть: знаниями в области изобразительной и формальной компози- } \\
\text { ции на плоскости и трехмерной форме; современным инструментарием и } \\
\text { разнообразием приемов графического языка; методами изображения и } \\
\text { моделирования градостроительной формы и пространства с помощью } \\
\text { ручной и компьютерной графики }\end{array}$ \\
\hline
\end{tabular}

Таким образом, для дисциплины «Профессиональная практика (архитектурное законодательство и нормирование, архитектурная этика, архитектурный менеджмент и администрирование)» (уровень магистратура) генеральные цели при ее изучении остаются неизменными и направлены на развитие профессионально значимых личностных творческих качеств студентов и создание условий для формирования индивидуального творческого стиля деятельности. Проприетарные цели при выполнении кейсового творческого задания в рамках практического занятия, по указанной дисциплине будут следующими:

1) создание условий для развития положительной мотивации к активному поиску, анализу и дальнейшей творческой обработке необходимой профессиональной информации;

2) направление вектора учебнотворческой деятельности студентов на использование полученных знаний и умений в квазипрофессиональной деятельности;
3) отработка умения применять полученные знания при построении модели взаимодействия между участниками процесса архитектурно-градостроительного проектирования;

отработка владения средствами профессиональной коммуникации, в том числе, графическими приемами подачи выполненного задания.

Указанные цели сформулированы с опорой на общекультурную компетенцию ОК-4, установленную для дисциплины образовательной программой высшего образования для направления «Архитектура» уровень магистратура «Орловского государственного университета имени И.С. Тургенева» в соответствии с ФГОС ${ }^{3}$, и которая предполагает формирование в образовательном процессе способности использовать

\footnotetext{
3 Федеральный государственный образовательный стандарт высшего образования по направлению подготовки 07.04.01 Архитектура уровень магистратура Утвержден Мин. Образования и науки 08.10.2015г. №39235 URL: http://fgosvo.ru/uploadfiles/fgosvom/070401.pdf (дата обращения: 12.10.2019)
} 
практические умения и навыки в организации исследовательских и проектных работ, в управлении коллективом. При этом процесс формирования необходимых знаний, умений и владений предлагается организовывать таким образом, чтобы, выполняя кейсовое практическое задание студенты имели возможность проявить себя с индивидуально-творческой позиции. Индикаторы сформированности компетенции ОК-4, установленные образовательной программой представлены в табл. 2:

Таблица 2

\section{Индикаторы достижения сформированности общекультурной компетенции ОК-4}

Table 2

\section{Indicators of achieving the formation of general cultural competence GC-4}

\begin{tabular}{|c|l|}
\hline $\begin{array}{c}\text { Код } \\
\text { компетенции }\end{array}$ & $\begin{array}{l}\text { Индикаторы достижения компетенции (для планирования } \\
\text { результатов обучения по образовательной программе) }\end{array}$ \\
\hline \multirow{5}{*}{ ОК-4 } & $\begin{array}{l}\text { Знать: закономерности научно-проектного творчества; основные зако- } \\
\text { номерности формирования рынка проектных, экспертных, консульта- } \\
\text { ционных услуг. }\end{array}$ \\
\cline { 2 - 3 } & $\begin{array}{l}\text { Уметь: сопоставлять различные, часто противоположные мнения на } \\
\text { одно и то же явление; выявлять общие закономерности и принципы } \\
\text { решения проблемных ситуаций; суммировать полученные знания и } \\
\text { выялять на этой основе собственную точку зрения, подкрепленную } \\
\text { научно обоснованными фактами. }\end{array}$ \\
\cline { 2 - 3 } & $\begin{array}{l}\text { Владеть: достаточным практическим опытом и теоретическими знани- } \\
\text { ями, необходимыми для решения поставленных задач; проектной } \\
\text { культурой и творческим мышлением - профессионально-значимыми } \\
\text { качествами в структуре личности архитектора. }\end{array}$ \\
\hline
\end{tabular}

Определение целевой составляющей образовательной технологии означает переход к следующему этапу конструирования образовательной технологии: подбору и структурированию содержания образования, а также выбору методов и форм организации познавательно-творческой деятельности обучающихся. Важной характеристикой данного этапа проектирования образовательной технологии является научный подход к подбору содержания образования, так как, определяя личностно-творческое развитие приоритетным направлением, в котором предлагается развивать архитектурноградостроительное образование, следует делать выбор в пользу креативных педагогических технологий, базирующихся на сборе, изучении и компиляции научного материала по педагогике творчества и развития личности, пропущенного через призму специфики архитектурно-градостроительного образо- вания. С этой целью были изучены результаты научных исследований, как педагогов архитектурно-градостроительного образования, так и исследователей индивидуального творческого стиля деятельности на специальностях, связанных с творчеством (художник, дизайнер, конструктормодельер) Е.М. Чибиревой, Л.А. Сафиной, Т.В. Костогриз, К.В. Филатовой. Большой интерес представляет научно-методическое обеспечение развития творческого потенциала у студентов архитекторов, разработанное И.В. Бесединой. Изучены формы, средства и методы обучения, обеспечивающие эффективное развитие интереса у студентов архитекторов к художественно-творческой деятельности, предложенные О.М. Шенцовой. Заслуживает особого внимания электронный ресурс художника, архитектора, педагога Московского архитектурного института (МАРХИ) Е.В. Тарутиной, разрабо- 
тавшей оригинальные самобытные методики поиска вдохновения и настройки на творчество.

Для осуществления более точного выбора методик и технологий педагогики творчества, способствующих формированию индивидуального творческого стиля деятельности у будущих архитекторов и градостроителей необходима диагностика, показывающая слабые стороны решения этого вопроса и основные противоречия при реализации существующей модели архитектурно-градостроительного образования. Учет индивидуально-творческих характеристик и особенностей контрольных групп студентов, позволяет не только сместить акценты в нужном направлении для образовательного процесса в целом, но и конкретизировать задачи в рамках изучения отдельных дисциплин.

В частности, анкетирование студентов архитекторов в рамках констатирующего эксперимента показало неспособность использовать различные технологии погружения в творчество, творческого раскрепощения и творческой самоидентификации. Так, при проведении анкетирования в группе из 22 студентов архитекторов 4 курса на вопрос использует ли студент какие-либо технологии погружения в творчество и, если да, то какие - 10 человек ответили отрицательно, причем 6 из них ответили, что не знают или не понимают, что это такое в принципе. 6 человек используют музыку в качестве побудительного мотива к творческой деятельности, 5 с этой целью просматривает работы известных архитекторов и произведения искусства, 1 человек указал в этом качестве медитацию. Следовательно, более $40 \%$ студентов практически не владеют способами и приемами осознанного творчества. Если учитывать тот факт, что прослушивание музыки является эмоциональным фоном для творчества, медитация способом самоконцентрации, а просматриваемые реализованные объекты предпроектным анализом, то можно говорить о практически полном отсутствии представлений у данной группы студентов о спосо- бах настройки на творческую деятельность. Анкетирование в группе студентов архитекторов 2 курса из 15 человек дало практически такой же количественный результат: 7 человек не используют никаких технологий погружения, из них двое не знают, что это такое, 6 полагают, что таковой является прослушивание музыки и двое относят к данным технологиям просмотр шедевров искусства.

Учитывая тот факт, что систематическое, фактически ежедневное творчество является основой профессиональной деятельности архитектора и градостроителя, полученные результаты диагностики свидетельствуют о том, что, в рамках реализации архитектурно-градостроительной образовательной программы, нацеленной на формирование индивидуального творческого стиля деятельности необходимо менять подходы к передаче материала, касающегося творческих дисциплин, следует наполнять содержание образования методиками, способствующими формированию стабильного интереса к творческой деятельности, стремления к самостоятельному поиску профессионально значимых знаний и умений, стремления к осуществлению творческой деятельности по собственной программе. Кроме того, совершенно необходимо всячески мотивировать и поощрять в студентах стремление к творческой самоидентификации.

Важно подчеркнуть, что при педагогическом наблюдении за студентами при применении одной из технологий в рамках практических занятий, было замечено, что студенты с удовольствием настраиваются и погружаются в творчество, активно работают на занятиях в университете и выполняют домашние задания. Несмотря на то, что задания носят индивидуальный характер, оно служит толчком к активному обсуждению выполненных работ и примененных графических техник. Дополнительной мотивационной составляющей является возможность участия студентов в открытом Всероссийском творческом конкурсе «Город своими руками», проходящим в архитектурно- 
строительном институте г. Орла, в рамках которого выполненные работы представляются на конкурсной площадке архитектурной графики «Поиск творческого Я. Перевоплощение в мастера». Из лучших работ обычно формируется выставка, по итогам просмотра которой, конкурсная комиссия определяет призовые места. Победители награждаются дипломами.

В рамках настоящей статьи невозможно подробно расписать все этапы и нюансы проектирования и конструирования содержательной части педагогической технологии, способствующей формированию индивидуального творческого стиля деятельности у будущих архитекторов и градостроителей, однако результаты анализа научнопедагогических материалов, посвященных этой проблематике, а также результаты проведённой экспериментальной работы показывают, что, в первую очередь, предпочтительны следующие методы: метод кейсов, метод моделирования, использование различных методик развития творческого потенциала и настройки на творческую деятельность.

Следует добавить, что еще одним, несомненно, важным аспектом успешной реализации модели формирования индивидуального творческого стиля деятельности у студентов архитекторов и градостроителей является педагогическое творчество преподавательского состава. Так как профессии архитектора и градостроителя уникальны, а задача профессионального архитектурного и градостроительного образования заключается в подготовке специалиста-профессионала с ярко выраженными личностнотворческими характеристиками, то в процессе реализации образовательной программы педагогу необходимо систематическое переосмысление содержания образования. Требуется изучение самобытных методик других архитектурных вузов, а также творческих архитектурно-градостроительных и художественных мастерских, сохранение и дальнейшее развитие гуманитарнохудожественных традиций российского ар- хитектурно-градостроительного образования, развитие сотрудничества с зарубежными архитектурно-градостроительными школами, особенно в конструктивнотехнологической сфере.

На заключительном этапе проектирования и конструирования педагогической технологии, способствующей формированию индивидуального творческого стиля деятельности у студентов архитекторов и градостроителей требуется определить методы и средства контроля полученных результатов. Как уже упоминалось выше, индивидуальный творческий стиль деятельности не может быть сформирован в рамках какого-либо занятия, дисциплины и даже целого курса обучения. Это перманентный процесс, длящийся в течение всей профессионально-творческой жизни, при этом основы его необходимо формировать в процессе приобретения профессионального образования. Кроме того, важно отметить факт, что индивидуальный творческий стиль деятельности является сугубо личностной характеристикой, зависит от личностно-творческих качеств каждого отдельно взятого индивида и в каждом конкретном случае будет проявляться с той или иной степенью выразительности. Учитывая вышесказанное, для проверки эффективности формирования индивидуального творческого стиля деятельности у студентов архитекторов и градостроителей в вузе был разработан критериально-оценочный блок, отражающий основные критерии и показатели, а также уровни сформированности индивидуального творческого стиля деятельности у студентов (табл. 3).

В процессе реализации педагогической технологии проверить наличие тех или иных показателей сформированности индивидуального творческого стиля деятельности можно с помощью таких эмпирических методов, как: метод педагогического наблюдения, в частности включенное наблюдение, метод беседы, интервью, метод рейтинга, метод педагогического консилиума. 
Таблица 3

Основные критерии, показатели и уровни сформированности индивидуального творческого стиля деятельности у студентов

Table 3

\section{The main criteria, indicators and levels of formation of an individual creative style of activity among students}

\begin{tabular}{|c|c|c|c|c|}
\hline \multirow{6}{*}{ 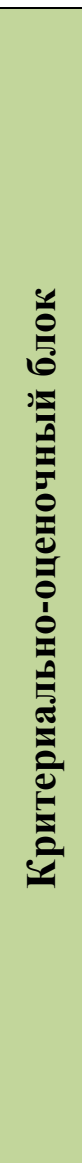 } & \multicolumn{4}{|c|}{ Критерии сформированности индивидуального творческого стиля деятельности } \\
\hline & мотивационный & когнитивный & деятельностный & личностный \\
\hline & \multicolumn{4}{|c|}{ Показатели сформированности индивидуального творческого стиля деятельности } \\
\hline & $\begin{array}{l}\text { Наличие устойчи- } \\
\text { вого мотива и по- } \\
\text { требности к твор- } \\
\text { честву и к прояв- } \\
\text { лению индивиду- } \\
\text { альности в твор- } \\
\text { ческой деятельно- } \\
\text { сти архитектора. } \\
\text { Стремление к са- } \\
\text { мообразованию и } \\
\text { саморазвитию }\end{array}$ & $\begin{array}{l}\text { Наличие системы } \\
\text { знаний о средствах } \\
\text { и способах дей- } \\
\text { ствий, необходи- } \\
\text { мых для осу- } \\
\text { ществления про- } \\
\text { фессиональной де- } \\
\text { ятельности архи- } \\
\text { тектора и градо- } \\
\text { строителя }\end{array}$ & $\begin{array}{l}\text { Способность к } \\
\text { выполнению сово- } \\
\text { купности действий } \\
\text { по поиску, полу- } \\
\text { чению и обработке } \\
\text { информации (ана- } \\
\text { лиз, структуриро- } \\
\text { вание, обобщение } \\
\text { и т.п.) Способ- } \\
\text { ность к решению } \\
\text { задач различного } \\
\text { уровня когнитив- } \\
\text { ной требователь- } \\
\text { ности. Владение } \\
\text { комплексом } \\
\text { средств професси- } \\
\text { ональной комму- } \\
\text { никации }\end{array}$ & $\begin{array}{l}\text { Сформированность } \\
\text { профессионально- } \\
\text { значимых качеств } \\
\text { личности, стремле- } \\
\text { ние к осуществле- } \\
\text { нию творческой дея- } \\
\text { тельности по соб- } \\
\text { ственной програм- } \\
\text { ме. Когитальное } \\
\text { мышление. Лич- } \\
\text { ностные смыслы со- } \\
\text { держания творче- } \\
\text { ской деятельности }\end{array}$ \\
\hline & \multicolumn{4}{|c|}{ Уровни сформированности индивидуального творческого стиля деятельности } \\
\hline & Пороговый (минимальный) & \multicolumn{2}{|c|}{ Повышенный } & $\begin{array}{l}\text { Высокий (субъектно- } \\
\text { творческий) }\end{array}$ \\
\hline
\end{tabular}

Кроме того, в рамках реализации образовательной программы для каждой дисциплины разрабатывается фонд оценочных средств. Как уже упоминалось выше, сформулированные в образовательных стандартах компетенции не только не вступают в противоречие с индивидуальным творческим стилем деятельности, но даже подчеркивают необходимость его формирования. Следовательно, фонды оценочных средств дисциплин также являются отражением сформированности индивидуального творческого стиля деятельности. Методами диагностического контроля, отраженными в фондах оценочных средств, является метод диагностирующих контрольных работ, в частности это расчётно-графические работы, курсовые работы, курсовые проекты, рефераты и т.п. Для творческих дисциплин оценке в таких случаях подлежат не только степень и качество проработки выполненной задачи, оценивается творческий замысел автора, новаторство его авторской концепции, мастерство визуально-графической подачи проектного материала и т.п.

Заключение (Conclusions). Проведенный анализ социального заказа государства и общества на подготовку современного специалиста архитектора, градостроителя, выявил потребность формирования у студентов, обучающихся на этих специальностях, такой личностной профессиональной характеристики, как индивидуальный твор- 
ческий стиль деятельности. Установлено, что для реализации замысла его формирования в образовательном процессе необходима специальная профессиональноориентированная технология обучения. Определены основные этапы ее проектирования и конструирования: определение целей, подбор содержания образования с учетом процессуальных механизмов педагогической поддержки личностно-творческого развития и формирования индивидуального творческого стиля деятельности, выбор методов и форм организации познавательнотворческой деятельности обучающихся, определение форм и средств контроля. В качестве основных методов и форм организации учебно-познавательной и квазипрофессиональной деятельности, способствующих достижению поставленных педагогических целей определены: метод кейсов, метод моделирования, использование различных методик развития творческого потенциала и настройки на творческую деятельность. В соответствии с разработанным критериально-оценочным блоком, отражающим основные критерии и показатели, а также уровни сформированности индивидуального творческого стиля деятельности у студентов, предложен диагностический аппарат, позволяющий проверить наличие показателей его сформированности. В частности, это методы включенного наблюдения, беседы, интервью, метод рейтинга и метод педагогического консилиума.

Экспериментальная работа, проведенная в архитектурно-строительном институте «Орловского государственного университета им. И.С. Тургенева», подтвердила результативность предлагаемой технологии.

Учитывая вышеизложенное, можно говорить о том, что применение в архитектурно-градостроительном образовании педагогической технологии, краткое описание которой приведено в настоящей статье, способствует формированию и дальнейшему развитию индивидуально-творческих профессиональных характеристик у обучающихся и, как следствие, индивидуального творческого стиля деятельности у будущих архитекторов и градостроителей в вузе.

\section{Список литературы}

Андреев В.И. Законы творческого саморазвития как основания концепции субъектноориентированного образования // Вестник Казанского технологического университета. 2013. №16. С. 13-16.

Беседина И.В. Развитие творческого потенциала будущих архитекторов в профессиональном образовании // Социально-гуманитарный вестник Прикаспия: научный журнал / Астраханский государственный архитектурностроительный университет. Астрахань: ГАОУ АО ВО «АГАСУ». 2017. № 1-2 (6-7). С. 48-53.

Волосатова И.Ю. Индивидуальнотворческий подход к формированию художественно-творческих способностей студентов колледжа // Научные Исследования в Образовании, Издательство: Академия профессионального образования (Москва). 2009. №10. С. 22-26

Зайцев В.С. Современные педагогические технологии. В 2-х книгах. Книга 1. Челябинск. ЧГПУ. 2012. $411 \mathrm{c.}$

Мартишина Н.В. Творческий потенциал педагога: теория и опыт развития // Известия ВГПУ. 2015. №8. С. 29-35

Миронова И.А. Индивидуальный творческий стиль деятельности в архитектурном образовании как педагогический феномен // Педагогический журнал. 2018. Т.8. № 2А, С 231-237.

Миронова И.А. Модель формирования индивидуального творческого стиля деятельности у будущих архитекторов и градостроителей в вузе. // Ученые записки Орловского государственного университета. №3 (84). 2019.

Образцов П.И. Технология обучения: современная интерпретация в профессиональной педагогике // Ученые записки Орловского государственного университета. Серия: Гуманитарные и социальные науки. 2016. № 4 (73). C. 311-315.

Образцов П.И., Уман А.И., Виленский М.Я. Технология профессиональноориентированного обучения в высшей школе Учебное пособие. Издание третье / Под ред. В.А. Сластенина. М.: Юрайт, 2018. 272 с.

Пак Л.Г., Беседина И.В. Возможности профессионального образования в развитии творческого потенциала будущих архитекторов, Вестник Оренбургского государственного педагогического университета, электронный науч- 
ный журнал, №2(14), 2015, C. 169-174 URL http://vestospu.ru/archive/2015/articles/20_14_2015 .pdf (Дата обращения 18 ноября 2019)

Педагогика: педагогические теории, системы, технологии: Учеб. для студ. высш. и сред. пед. учеб. заведений / С.А. Смирнов, И.Б. Котова, Е.Н. Шиянов и др.; Под ред. С.А. Смирнова. 4-е изд., испр. М.: Издательский центр «Академия», 2000. 512 с.

Педагогический словарь: учеб. пособие для студ. высш. учеб. заведений / В.И. Загвязинский, А.Ф. Закирова, Т.А. Строкова и др.; под ред. В.И. Загвязинского, А.Ф. Закировой. М.: Издательский центр «Академия», 2008. 352 с.

Селевко Г.К. Энциклопедия образовательных технологий. В 2-х т. Т. 1. М.: Народное образование. 2005.816 с.

Сериков В.В. Развитие личности в образовательном процессе: монография. М.: Логос. 2012. 448c.

Юдин В.В. Технологическое проектирование педагогического процесса: монография / В.В. Юдин. Москва: Университетская книга. 2008. $300 \mathrm{c}$.

\section{References}

Andreev, V.I. (2013), "Laws of creative selfdevelopment as the basis of the concept of subjectoriented education", Vestnik Kazanskogo tehnologicheskogo universiteta, 16, 13-16. (In Russian).

Besedina, I.V. (2017), "Development of creative potential of future architects in professional education", Social and humanitarian Bulletin of the Caspian region: scientific journal, 1-2 (6-7), 4853. (In Russian).

Volosatova, I.Yu. (2009), "Individual creative approach to the formation of artistic and creative abilities of College students", Research in Education, 10, 22-26. (In Russian).

Zaitsev, VS. (2012), Sovremennyye pedagogicheskiye tekhnologii [Modern pedagogical technologies], Chelyabinsk, Russia.

Martishina, N.V. (2015), "Creative potential of a teacher: theory and experience of development", Proceedings of the Volgograd state pedagogical University, 8, 29-35. (In Russian).

Mironova, I.A. (2018), "Individual creative style of activity in architectural education as a pedagogical phenomenon", Pedagogical Journal, 8 (2A), 231-237. (In Russian).

Mironova, I.A. (2019), "The model of formation of an individual creative style of activity of future architects and city planners", Scientific notes of Orel State University, 3 (84), 278 -281. (In Russian).

Obraztsov, P.I. (2016), "Technology of teaching: modern interpretation of the professional pedagogy", Scientific notes of Orel State University, 4 (73), 311-315. (In Russian).

Obraztsov, P.I., Uman, A.I. and Vilensky M.Y., (2018), Tekhnologiya professional'nooriyentirovannogo obucheniya $v$ vysshey shkole [Technology of professionally-oriented education in a Higher School] in Slastenina, V.A. (ed.), Yurait, Moscow, Russia.

Pak, L.G. and Besedina, I.V. (2015), "Possibilities of professional education in the development of the creative potential of future architects", Bulletin of the Orenburg state pedagogical University, available at: http://vestospu.ru/archive/2015/articles/20_14_2015 .pdf (Accessed 18 November 2019).

Smirnov, S.A., Kotova, I.B. and Shiyanov, E.N. (2000) Pedagogika: pedagogitcheskie teoriyi, sistemy, tehnokogiyi [Pedagogy: pedagogical theories, systems, and technologies], in Smirnov S.A (ed.), Academy, Moscow, Russia.

Zagvyazinsky, V.I., Zakirova, A.F. and Strokova, T.A. (2008), Pedagogical dictionary: a guide for students of higher educational institutions [Pedagogicheskiy slovar'], Academy, Moscow, Russia.

Selevko, G.K. (2005), Entsiklopediya obrazovatel'nykh tekhnologiy [Encyclopedia of educational technologies], Moscow, Russia.

Serikov, V.V. (2012), Razvitiye lichnosti v obrazovatel'nom protsesse [Personal development in the educational process], Moscow, Russia.

Judin, V.V. (2008), Technological design of the pedagogical process: monograph, Moscow, Russia.

Информация о конфликте интересов: авторы не имеют конфликта интересов для декларации. Conflicts of Interest: the authors have no conflict of interest to declare.

\section{Данные авторов:}

Миронова Инна Александровна, старший преподаватель кафедры архитектуры, Орловский государственный университет имени И.С. Тургенева. ORCID: 0000-0002-4246-049X. 
Образцов Павел Иванович, профессор, доктор педагогических наук, профессор кафедры технологий психолого-педагогического и специального образования, Орловский государственный университет им. И.С. Тургенева.

\section{About the authors:}

Inna Al. Mironova, Senior Lecturer, Department of Architecture, Orel State University named after I.S. Turgenev. ORCID: 0000-0002-4246-049X.

Pavel I. Obraztsov, Doctor of Pedagogical Sciences, Professor of the Department of Technology of Psychological and Pedagogical and Special Education, Orel State University named after I.S. Turgenev.

\section{Заявленный вклад соавторов:}

Миронова И.А. изучение концепции, сбор данных и доказательств, проведение экспериментов; развитие методологии, подготовка начального варианта текста

Образцов П.И. научное руководство, курирование данных, критический анализ и доработка текста

\section{Contribution of the authors:}

I. A. Mironova: studying the concept, collecting data and evidence, conducting experiments, developing the methodology, preparing the initial version of the text.

P. I. Obraztsov: scientific guidance, data curation, critical analysis and text revision 